Article

\title{
Correlation OfMaternal Serum Ferritin With Cord Blood Dopamine Concentration
}

\author{
Wulan Dewi Rizky ${ }^{l}$, VaulinneBasyir ${ }^{2}$, Rima Semiarty ${ }^{3}$ \\ ${ }^{1}$ Program Of Magister Biomedic, Faculty Of Medicine, Andalas University, Indonesia \\ ${ }^{2}$ Department of Obstetric and Gynekology, Faculty Of Medicine, AndalasUniversit,Indonesia \\ ${ }^{3}$ Department Of Public Health And Community Medicine, Faculty of medicine, Andalas University, Indonesia
}

\begin{tabular}{l}
\hline SUBMISSION TRACK \\
\hline Recieved: \\
Final Revision: \\
Available Online: \\
KEYWORDS \\
\hline
\end{tabular}

serum feritin, dopamine, cord

CORRESPONDENCE

Phone: 085272799967

E-mail: wu_rha@yahoo.co.id

\begin{abstract}
A B S T R A C T
Anemia in pregnancy is a common health problems today, where iron deficiency is the main cause. Iron deficiency will affect the various organs and metabolic pathways, especially the central dopamine pathway. Dopamine is a neurotransmitter that is found in brain and affects human interpersonal actions and correlations. The purpose of this study was to determine the correlation of maternal serum feritin with cord blood dopamine concentration. The design of this study was cross sectional, observe 30 pregnant women with their babies born in Rika Hardi, SSiTmaternity clinic. Samples were selected by consecutive sampling. Ferritin and dopamine concentration was checked at BalaiLaboratoriumKesehatan West Sumatera, where ferritin concentration by ECLIA and dopamine concentration by ELISA. Data were analyzed with Spearman correlation test to find the correlation of maternal serum feritin with cord blood dopamine concentration. The study results obtained, mean concentration of maternal serum ferritin 33,21+26,08 $n g / m L$ and cord blood dopamine concentration $172,27 \pm 27,21 \mathrm{ng} / \mathrm{L}$. Correlation test of maternal serum feritin with cord blood dopamine concentration had $p$ value $=0,301(p>0,05)$. In this study, we can conclude that there is no correlation between maternal serum feritin with cord blood dopamine concentration.Further research is needed by considering various factors that affect maternal ferritin concentration such as food intake and iron supplementation, and which affect dopamine concentration, such as stress and adequate sleep.
\end{abstract}

\section{INTRODUCTION}

Pregnant women are one of the groups that are susceptible to malnutrition. During pregnancy mother and the fetus must increase nutrition needs because it must meet the nutritional needs of the mother and the fetus. Therefore, pregnant women need to pay attention to nutrition intake. Mistakes in this case will adversely affect the mother and the embryo. Anemia in pregnancy is one of 
the most common health problems today. WHO (2011) showed that in the age of 15-49 years there were approximately 32.4 million cases of anemia in pregnancy or by $38 \%$. The countries of Southeast Asia, Western Mediterranean, and Africa are the areas with the most cases. For Southeast Asia, Indonesia and Thailand are ranked fourth highest, higher than Malaysia (27\%) and Singapore (28\%)

(WHO, 2015).Riskesdas(2013) recorded the prevalence of anemia in pregnant women in Indonesia by $37.1 \%$; higher than (2007) which amounted to $24.5 \%$ (Ministry of Health RI, 2013).

The USAID's A2Z Micronutrient and Child Blindness Project, ACCESS Program, and Food and Nutrition Technical Assistance (FANTA) Project (2006) report that about $50 \%$ of all types of anemia are estimated to result from iron deficiency (USAID et al., 2006). WHO scores are not much different, estimated at about 30-40\% (WHO, 2015).

Many other studies also explain that iron deficiency is a major cause of anemia in pregnancy. An example is a study conducted by Sukrat and Sirichotiyakul in Thailand (2006), there is $43.1 \%$ of anemia in pregnancy was due to iron deficiency. Research in Malawi also found out of 150 pregnant women, $32 \%$ of whom had iron deficiency and one or more micronutrients (Van den Broek and Letsky, 2000). In Tanzania also showed correlation anemia of pregnant women with iron deficiency (Hinderaker et al., 2002).

Anemia during pregnancy has a correlation with low birth weight, preterm birth, fetal death, and inadequate iron reserves in newborns. This condition will cause high perinatal and maternal, and also morbidity is still high (Ahmad et al., 2010). According to Putri et al. (2015) in Semarang district it was found that out of 126 pregnant women with anemia who experienced abortus as many as 91 people (40.6\%).

The amount of iron in the body can be assessed by measuring ferritin concentration, because iron is stored in this form. Availability of sufficient ferritin during pregnancy will be very beneficial for the development of the baby's brain. Ferritin plays a role in determining the intelligence of a child from the womb. Perinatal ferritin deficiency will have an impact on subsequent life, because of its role in neurocognitive and neurobehavioral development in the final two thirds of pregnancy (Estrada, 2014).

Ferritin is involved in various neurological functions. The existing ferritin will be able to support neuronal and glial energy metabolism, dendritic arborization, synaptogenesis, neurotransmitter synthesis, myelination. Ferritin deficiency affects behavior, where one becomes apathetic, emotional, fatigue, lack of concentration, often anxiety, hypoactivity, and decreased cognition and attention (Oski, 1993).

Ferritin deficiency will affect various organs and metabolic pathways, and the most sensitive of these are central dopamine pathways. Dopamine is a neurotransmitter found in the brain. These chemicals are called center of brain power. Most human interpersonal actions and correlations are influenced by this substance. Dopamine plays a role in regulating behavior and cognition, motivation, inhibiting prolactin production, plays in sleep, dreams, emotions, attention, working memory, and learning (Beard et al., 2006; Calabresi et al., 2007).

The correlation between ferritin and dopamine function has been studied for a long time in various experimental animals. The effect of ferritin and dopamine developed rapidly during early life in line 
with the increase in the number and density of dopamine transporters and their receptors. Ferritin is associated with monoamine oxidase activity, which is an enzyme that is important for the degradation of neurotransmitters. Ferritin is localized to dopaminergic nerves throughout the brain, extracellular dopamine and norepinephrine are elevated in the brains of iron-deficient mice, but other neurotransmitters do not. In addition, the loss of ferritin concentration in the brain is specific to certain areas of the brain and is a heterogeneous effect of dopamine neurology, whereas in areas where concentration do not fall, there is no change in dopamine (Erikson et al., 2001).

The number of problems regarding ferritin in pregnant women that will affect the development of the fetus, and no studies that see the correlationferitinconcentration of pregnant women aterm with dopamine concentration, the authors feel the need to conduct further research. Based on the description above, the authors are interested in conducting a study entitled "Correlation of maternal serum feritin with cord blood dopamine concentration ".

\section{METHODS}

The design of this study was cross sectional, observe 30 pregnant women with their babies born in Rika Hardimaternity clinic. Samples were selected by consecutive sampling. Ferritin and dopamine concentration was checked at Balai Laboratorium Kesehatan West Sumatera, where ferritin concentration by ECLIA and dopamine concentration by ELISA. This research was conducted in Aprilto May 2018.

\section{RESULT}

Characteristics of Respondents In this study, the characteristics of 30 pregnant women aterm are shown in the following table.
Mean age, parity and gestational age of the respondent

\begin{tabular}{cccccc}
\hline Karakteristik & Mean & SD & Med & Min & Max \\
\hline $\begin{array}{c}\text { Age of } \\
\text { pregnant } \\
\text { women } \\
\text { Paritas (ke-) }\end{array}$ & 29,43 & 6,04 & 28 & 18 & 41 \\
$\begin{array}{c}\text { Usiakehamilan } \\
\text { (minggu) }\end{array}$ & 39,50 & 0,78 & 40 & 38 & 41 \\
\hline
\end{tabular}

shows that the mean age of pregnant women is at the fertile age, is $29.43 \pm 6.04$ years. The mean parity was $2.27 \pm 1.53$, and the mean of pregnancy of the respondent was aterm, is $39.53 \pm 0.78$ weeks.

\section{Univariate Analysis}

Univariate analysis is an analysis performed on each research variable. Univariate analysis was used to find out the description of the distribution of research variables including serum ferritin and serum dopamine concentration. The analysis results are as follows:

\section{Average Concentration of Ferritin and}

\section{Dopamine for Pregnant Women}

Mean of ferritin and dopamine concentration of pregnant women in this study can be seen in the following table.

\section{Respondents' ferritin and dopamine} concentration

\begin{tabular}{cccccc}
\hline Variabel & Mean & SD & Med & Min & Max \\
\hline $\begin{array}{c}\text { Feritin } \\
(\mathbf{n g} / \mathbf{m L})\end{array}$ & 33,21 & 26,08 & 23,81 & 10,05 & 93,97 \\
$\begin{array}{c}\text { Dopamin } \\
(\mathbf{n g} / \mathbf{L})\end{array}$ & 172,27 & 27,21 & 173,25 & 120,00 & 217,5 \\
\hline
\end{tabular}

In table 3.2 it appears that the mean ferritin level of respondents is normal, which is $33.21 \pm 26.08 \mathrm{ng} / \mathrm{mL}$ where the normal mean ferritin of third trimester pregnant women> $39 \mathrm{ng} / \mathrm{Ml}$. The mean dopamine value was $172.27 \pm 27.21 \mathrm{ng} / \mathrm{L}$. In this study, the data distribution test showed that the dopamine content data was normally distributed, while the ferritin content was not 
normally distributed. After transformation, ferritin content data remained not normally distributed. Therefore, an analysis of the correlation between ferritin concentration and dopamine concentration of the umbilical cord was used to test the Spearman

\section{DISCUSSION}

This research was conducted on 30 people at term pregnant women and gave birth in Rika Hardimaternity clinic.

\section{UnivariateAnalysis}

\section{Average of Ferritin Concentration and cord blood Dopamine}

Serum ferritin is a measure of iron storage in body tissues. Low concentration of ferritin become an early sign of iron deficiency and anemia (Millichap et al., 2006).

Ferritin is currently considered the most important indicator in determining iron status in the iron deficiency stage wherein the concentration will decrease. However, ferritin will increase due to several factors such as infection and inflammation in pregnant women, so high values not always indicate good iron status. feritinneeds of pregnant women aterm is about $39 \mathrm{ng} / \mathrm{mL}$. In this study, $70 \%$ of the samples had ferritin concentration below their needs. That is, there are still many pregnant women who have iron deficiency, which in turn will affect the occurrence of anemia during pregnancy. This is accordance with Riskesdas(2013) which recorded the prevalence of anemia in pregnant women in Indonesia is still quite high, at 37.1\%; higher than 2007 which amounted to $24.5 \%$ (Ministry of Health RI, 2005; Ministry of Health RI, 2013).

The mean dopamine concentration in this study was 172,27 $\pm 27,21 \mathrm{ng} / \mathrm{L}$. Dopamine is associated with modulation of correlation. The results of the analysis show that there is no significant correlation between the two variables ( $p>0.05$ ). Thus, the value of $r$ does not need to be calculated again.

psychomotor activity and executive function. Dopamine works by reprogramming brain function through the process of increasing the stimulation of the synapse in the course of a person's behavior (Tumbelaka et al., 2012).

\section{Bivariate Analysis}

\section{Correlation OfMaternal Serum}

Feritin With Cord Blood Dopamine Concentration

Ferritin is a signal of iron storage in the body. Low ferritin concentration are an early sign of iron deficiency and anemia. Ferritin is an essential nutrient for mental, motor, and cognitive development. Ferritin is required in the production of tyrosine hydroxylase, an enzyme that plays a role in the production of levodopa, which then decarboxylates into dopamine (Connor \&Benkovic, 1992; Tumbelaka et al., 2012).

Dopamine plays an important role in various nervous system, ranging from regulating motor functions to regulating the emotional status and regulation of the hypothalamic-pituitary axis. Dopamine system disorders associated with aggressive behavior, obsessive compulsive, and excessive self-stimulation (Mardion, 1995; Pinzon, 2007).

Nutrition and growth factor play a role in brain development both at prenatal and postnatal. Many micronutrients are important for brain development, one of them is Fe.the impact of deficiency or micronutrient excess depends on when iron deficiency, how much and how long iron 
deficiency.

If Iron deficiency anemia occurs at less than

2 years of age the impact will be irreversible, and the study showed 6 of 8 children with iron deficiency anemia over 2 years of age supplemented with good results. (Riskesdas, 2103).

Deficiency of ferritin will decrease the activity of tyrosine hydroxylase. As a result, the synthesis of dopamine will decrease, which will lead to neurodegeneration and neurological abnormalities (Pinzon, 2007). In this study, an analysis of the correlation between ferritin and cord blood dopamine concentration of umbilical cord in maternal was used Spearman test, significant when $p$ $<0.05$. The results of the study, in which the analysis showed no significant correlation between maternal serum feritin with cord blood dopamine concentration $(\mathrm{p}=0.301$ ).

Research about maternal ferritin concentration with cord blood dopamine concentration has never been done before. Existing research is to look at the correlation of maternal ferritin concentration with cognitive and motory function in infants who are born. However, the studies cancaused as a reference for this study.

In this study, different results from previous studies have shown an association between maternal ferritin and cognitive and motor function of the infant born, which certainly indicates a link between ferritin and dopamine. As Grantham-McGregor \&Ani's 2001 study suggested that ferritin deficiency during pregnancy can lead to long-term cognitive and motor impairment in the baby being delivered. In addition, Siddappa et al. (2004) also found diabetic mothers with ferritin deficiency will give birth to infants with low concentrations of ferritin, which subsequently result in memory impairment in speech recognition (Grantham-McGregor \&Ani, 2001; Siddappa et al., 2004). Research in the United States in 1992 obtained results that support the results of this study. Based on the MMPI questionnaire, it was reported that ferritin and hemoglobin concentration were not associated with depression. Kiddie et al. (2010) and Oner\&Oner (2008) found no association between ferritin concentration with clinical symptoms and the severity of attention and hyperactivity disorders (GPPH) in children (Hunt \&Pelland, 1999; Kiddie et al., 2010; Oner\&Oner, 2008).

In this study, the researchers did not classify between iron deficiency anemia mothers and no iron deficiency anemia, thus affecting the results obtained. Grouping of pregnant women with anemia and no amemia is also needed, as the impact of ferritin on dopamine is more visible in women with low ferritin concentration. In addition, the use of iron or multivitamin supplements and other drugs that can affect serum ferritin concentration. Blood vapor level examination is also needed to rule out the possibility of inflammation or chronic infection that may affect ferritin concentration. However, C-reactive protein testing is believed to be more meaningful to rule out the possibility of infection.

Limitations of ResearchThis study has the following limitations:

1) There is no control over the stress management and lifestyle of respondents that may affect dopamine concentration.

2) Limitations do not predict the mother's pregnancy age 37-41 weeks with the results of ferritin and dopamine examination. 


\section{CONCLUSION}

The mean ferritin level of term pregnant women is $33.21 \pm 26.08$ $\mathrm{ng} / \mathrm{mL}$. The mean dopamine level of umbilical cord was $172.27 \pm 27.21$ $\mathrm{ng} / \mathrm{L}$. There is no correlation between ferritin concentration of term pregnant women with umbilical cord dopamine concentration. There are other factors that support ferritin concentration such as maternal food intake and iron supplementation and dopamine concentration in maternal stress, sleep disturbances and memory. 


\section{REFERENCES}

Abbaspour, N, Hurrell, R, Kelishadi, R, Review on iron and its importance for human health, J Res Med Sci, vol. 19, 2014, hh. 164-174.

Abboud, S \& Haile, DJ, A novel mammalian iron-regulated protein involved in intracellular iron metabolism, J BiolChem, vol. 275, 2000, hh. 19906-19912.

Achadi, Giziibudankesehatanreproduksi: gizidankesehatanmasyarakat, Raja GrafindoPersada, Jakarta. 2007.

Ahmad, N, Kalakoti, P, Bano, R, Aarif, SMM, The prevalence of anemia and associated factors in pregnant women in a rural Indian community, Australasian Medical Journal AMJ, vol. 3, 2010, hh. 276-280.

An, JH, Oh, BK, Choi, JW, Detection of tyrosine hydroxylase in dopaminergic neuron cell using gold nanoparticles-based barcode DNA, J Biomed Nanotechnol, vol. 9, 2013, hh. 639-643.

Andrews, NC, Forging a field: the golden age of iron biology, Blood, vol. 112, 2008, hh. 219-230.

Ballart, J. F., \& Murphy, M. M., Preventie nutritional supplementation throughout the reproductive life cycle.Public Health Nutrition. Pages 1363-1366.2001.

Beard, JL, Effectiveness and strategies of iron supplementation during pregnancy, Am J ClinNutr, vol. 71, 2000, hh.1288S-1294S.

Beard, JL, Erikson, KM, Jones, BC, Neonatal iron deficiency results in irreversible changes in dopamine function in rats, J Nutr, vol. 133, 2003, hh. 1174-1179.

Bothwell, TH, Iron requirements in pregnancy and strategies to meet them, American Journal Clinical Nutrition, hh. 247-256. 2000.

Buchta, WC \&Riegel, AC, Chronic cocaine disrupts mesocortical learning mechanisms, Brain Res, vol. 1628, 2015, hh. 88-103.

Burt, AM, Textbook of neuroanatomy, Saunders Company, Philadelphia.1993. 
Calabresi, P, Picconi, B, Tozzi, A, Di Filippo, M, Dopamine-mediated regulation of corticostriatal synaptic plasticity, Trends in Neurosciences, vol. 30, 2007, hh.211219.

Cheng, MH, Block, E, Hu, F, Cobanoglu, MC, Sorkin, A, Bahar, I, Insights into the modulation of dopamine transporter function by amphetamine, orphenadrine, and cocaine binding, Frontiers in Neurology, vol. 6,2015, hh.1-14.

Darwanty J, Antini A, The contribution of folic acid and hemoglobin concentration in pregnant women to fetal brain growth in filigree districts. hh 1-9.2011.

DepartementKesehatan RI, Kepmenkes RI No. 1593/2005, The number of nutritional adequacy recommended for the nationIndonesia, Jakarta. 2005.

Erikson, KM, Jones, BC, Hess, EJ, Zhang, Q, Beard, JL, Iron deficiency decreases dopamine D1 and D2 receptors in rat brain, PharmacolBiochemBehav, vol. 69, 2001. hh. 409-418.

Estrada, JA, Contreras, I, Pliego-Rivero, FB, Otero, GA, Molecular mechanism of cognitive impairment in iron deficiency: alterations in brain-derived neurotrophic factor and insulin-like growth factor expression and function in the central nervous system, NutrNeousci, vol.17, 2014, hh. 193-206.

FAO, Food based approaches to meeting vitamin and mineral needs, In: human vitamin and mineral requirements, hh. 7-25, Roma.2001.

Fleming, RE \& Bacon, BR, Orchestration of iron homeostasis, N Engl J Med, vol. 352, 2005.hh. 1741-1744.

Goddard, AF, James, MW, McIntyre, AS, Scott, BB, Guidelines For The Management Of Iron Deficiency Anaemia, Gut, vol. 60, 2011. hh. 1309-1316.

Guyton, AC \& Hall, JE, Buku ajar Fisiologikedokteran, EGC, Jakarta. 2002.

Halberg, L, Iron balance pregnancyand lactation in nutritional anemias, edited by Formon SJ and Zlotkin S Nestle Nutrition Workshop series 1992, Vol 30,2000, hh. 13-28.

Herbert, V, Iron disorders can mimic anything, so always test for them, Blood Rev.1992. 
Hinderaker, SG, Olsen, BE, Lie, RT et al, Anemia in pregnancy in rural Tanzania: associations with micronutrients status and infections. Eur J ClinNutr, vol. 56, 2002, hh. 192-199.

Hunt, JR, Zito, CA, Johnson, LA, Body iron excretion by healthy men and women', Am J ClinNutr, vol. 89,2009, hh. 1-7.

Hunt DL, Peland JG. Iron and depression in premenopausal women.An MMPI study.Beh Med. 1999;25:62-68.

Hurrell, R, Egli, I, Iron bioavailability and dietary reference values, Am J ClinNutr, vol. 91, 2010, hh.1461S-1467S.

Hurrell, RF, Bioavailability of iron, Eur J ClinNutr, vol. 51, 1997, hh.S4-S8.

KementerianKesehatan RI, RisetKesehatanDasar 2013, Kemenkes RI, Jakarta.2013.

Kiddie JY, Weiss MD, Kitts D, Levy-Milne R, Wasdell MB. Nutritional study of children with attention deficit hiperactivitydisoder: a pilot study. Int J Pediatr. 2010:1-7

Leknes, S \& Tracey, I, A common neurobiology for pain and pleasure, Nat Rev Neurosci, vol. 9, 2008, hh.314-320.

Lopez-Perez, SJ, Morales-Villagran, A, Medina-Ceja, L, Effect of perinatal asphyxia and carbamazepine treatment on cortical dopamine and DOPAC concentration, Journal of Biomedical Science, vol. 22,2015, hh. 1-7.

Mackenzie, B \& Garrick, MD, Iron imports. II. Iron uptake at the apical membrane in the intestine, Am J PhysiolGastrointest Liver Physiol.2005.

McKie, AT, Marciani, P, Rolfs, A, Brennan, K, Wehr, K, Barrow, D et al., A novel duodenal iron-regulated transporter, IREG1, implicated in the basolateral transfer of iron to the circulation, Mol Cell, vol. 5, 2000, hh. 299-309.

Millichap JG, Yee MM, Davidson S. Serum feritin in children with attention deficit hiperactivity disorder.Pediatr Neurol. 2006;34:200-203

Monk, C, Georgieff, MK, Xu, D, Hao, X, Bansal, R, Gustafsson, H et al., Maternal prenatal iron status and tissue organization in the neonatal brain, Pediatr Res, vol. 79,2016, hh. 482-488. 
Mora, JO \&Nestel, PS, Improving prenatal nutrition in developing countries: strategies, prospects, and challenges, Am J ClinNutr, vol. 71, 2000, hh. 1353S$1363 \mathrm{~S}$.

Mousseau, DD \& Baker, GB, Recent developments in the regulation of monoamine oxidase form and function: is the current model restricting our understanding of the breadth of contribution of monoamine oxidase to brain dysfunction, Curr Top Med Chem, vol. 12, 2012, hh. 2163-2176.

Munoz, GM, Campos, GA, García, EJA, Ramírez, RG, Fisiopathology of iron metabolism: diagnostic and therapeutic implications, Nefrologia, vol. 25, 2005, hh. 9-19.

Munoz, M, García-Erce, JA, Remacha, ÁF, Disorder of iron metabolism. Part 1: molecular basis of iron homeostasis, J ClinPathol, vol. 64, 2011, hh. 281-286.

Murray, R. K, Granner,D. K and Rodwell, V. W, Biokimia Harper. BukuKedokteran EGC, Jakarta.2009.

Muslimatun, S, Schmidt, MK, Schultink, W, West, CE, Hautvast, JGAJ, Gross, R et al., Weekly supplementation with iron and vitamin A during pregnancy increases hemoglobin concentration but decreases serum feritin concentration in Indonesian pregnant women, J Nutr, vol. 131,2006, hh. 85-90.

Nadadur, SS, Srirama, K, Mudipalli, A, Iron transport \& homeostasis mechanisms: their role in health \& disease, Indian J Med Res, vol. 128, 2008, hh. 533-544.

Olguin, HJ, Guzman, DC, Garcia, EH, Mejia, GB, The role of dopamine and its dysfunction as a consequence of oxidative stress, Hindawi Publishing Corporation, vol. 216, 2016, hh. 1-13.

Oski, FA, Iron deficiency in infancy and childhood, N Engl J Med, vol. 29, 1993, hh. 190-193.

Roodenburg, AJC, Iron supplementation during pregnancy, European Journal of Obstetric\& Gynecology and Reproductive Biology, vol. 61, 1995, hh. 65-71.

Rubi, B \&Maechler, P, Minireview: new roles for peripheral dopamine on metabolic control and tumor growth: let's seek the balance, Endocrinology, vol. 151,2010, hh. 5570-5581.

Sastroasmoro, S \& Ismael, S, Dasar-dasarmetodologipenelitianklinis, SagungSeto, Jakarta.2002. 
Scholl, TO \& Reilly, T, Anemia, iron, and pregnancy outcome, J Nutr, vol. 130, 2000, hh.443S-447S.

Scholl, TO. Iron status during pregnancy : setting the stage for mother and infant. American Journal of Clinical Nutrition. 81(suppl):1218S-1222S.2005.

Shao, J, Lou, J, Rao, R, Georgieff, MK, Kaciroti, N, Felt, BT et al, Serum feritin concentration is positively associated with newborn iron stores in women with low feritin status in late pregnancy, J Nutr, vol. 142,2012, hh. 2004-2009.

Steffensen, SC, Bradley,KD, Hansen, DM, Wilcox, JD, Wilcox, RS, Allison, DW et al., The role of connexin-36 gap junctions in alcohol intoxication and consumption, Synapse, vol. 65, 2011, hh. 695-707.

Sudoyo, AW, Setiyohadi, B, Alwi, I, Simadibrata, M, Setiati, Anemia defisiensibesidalamBuku Ajar IlmuPenyakitDalam, Jilid 2, Ed. 5, PusarPenerbitanIlmuPenyakitDalam, Jakarta, 2009, hh. 1128-1137.

Sukrat, B \&Sirichotiyakul, S, The prevalence and causes of anemia during pregnancy in MaharajNakorn Chiang Mai Hospital. J. Med. Assoc. Thai, vol. 89,2006, hh. S142-146.

Tumbelaka IA, Pusponegoro, HD, Rohsiswanto, R. Correlation between serum feritin level and attention deficit/hiperactivity disorder symptom scores in children based on the abbreviated conners teachers rating scale. PediatricaIndones. 2012;52:329335 .

Ulubay, S \&Dursun, Z, Cu nanoparticles incorporated polypyrrole modified GCE for sensitive simultaneous determination of dopamine and uric acid, Talanta, vol. 80, 2010, hh. 1461-1466.

USAID's A2Z Micronutrient and Child Blindness Project, ACCESS Program, dan Food and Nutrition Technical Assistance (FANTA) Project, Maternal anemia: a preventable killer, United States Government, Amerika.2006.

Van den Broek, NR \&Letsky, EA, Etiology of anemia in pregnancy in south Malawi, Am JClinNutr, vol.72, 2000, hh. 247S-256S.

Winkjosastro, H, IlmuKebidanan, YayasanBinaPustakaSarwonoPrawiroharjo, Jakarta.1999. 
World Health Organization, Worldwide prevalence of anemia 1993-2005: WHO global database on anemia.2008.

World Health Organization, The Global Prevalence of Anaemia in 2011, Geneva, Switzerland. 2015.

\section{BIOGRAPHY}

First Author :Her name is WulanDewiRizky. She was born in Padang, August 13, 1987. She began Her education at 6 years old in Pertiwi 3 Elementary School Padang. Then she continue Her school to public junior high school 25 Padang and finish it at 2002. She take PGRI 1 high school until 2005. Then continued Her education at DIII midwifery school in Mercubhaktijaya and graduate at 2008. She worked at PutriAndalas Midwifery School in 2008-2009. She already open independence practice of midwifery in 2009 while she worked at Mercubhaktijaya until 2010. She continued her education at D IV educator midwife polytechnic of health ministry and graduated in 2011. After that, she worked at midwifery academy Padang since 2011 until now. In 2014, she take master program on biomedic in Andalas university and graduated at July 2018. In 2014 and 2016, she published a journal in nightingale nursing journal of Indonesian health science college. In 2018, she also publish a book about reproductive health with HKI number:EC00201845187, 10 September 2018. 